University of Wollongong

Research Online

Faculty of Engineering - Papers (Archive)

Faculty of Engineering and Information

Sciences

2011

\title{
Nanoconfinement of lithium borohydride in Cu-MOFs towards low temperature dehydrogenation
}

\author{
W.W Sun \\ Fudan University \\ Shaofeng Li \\ Fudan University Shanghai \\ Jianfeng Mao \\ jm975@uowmail.edu.au \\ Zaiping Guo \\ University of Wollongong, zguo@uow.edu.au \\ Hua-Kun Liu \\ University of Wollongong, hua@uow.edu.au
}

See next page for additional authors

Follow this and additional works at: https://ro.uow.edu.au/engpapers

Part of the Engineering Commons

https://ro.uow.edu.au/engpapers/1352

\section{Recommended Citation}

Sun, W.W; Li, Shaofeng; Mao, Jianfeng; Guo, Zaiping; Liu, Hua-Kun; Dou, S. X.; and Yu, Xuebin:

Nanoconfinement of lithium borohydride in Cu-MOFs towards low temperature dehydrogenation 2011, 5673-5676.

https://ro.uow.edu.au/engpapers/1352

Research Online is the open access institutional repository for the University of Wollongong. For further information contact the UOW Library: research-pubs@uow.edu.au 
Authors

W.W Sun, Shaofeng Li, Jianfeng Mao, Zaiping Guo, Hua-Kun Liu, S. X. Dou, and Xuebin Yu 


\title{
Transactions
}

Cite this: Dalton Trans., 2011, 40,5673

wWW.rsc.org/dalton

COMMUNICATION

\section{Nanoconfinement of lithium borohydride in Cu-MOFs towards low temperature dehydrogenation $\uparrow$}

\author{
Weiwei Sun, ${ }^{a}$ Shaofeng Li, ${ }^{a}$ Jianfeng Mao, ${ }^{b}$ Zaiping Guo, ${ }^{* b}$ Huakun Liu, ${ }^{b}$ Shixue Dou ${ }^{b}$ and Xuebin Yu*a,b \\ Received 9th December 2010, Accepted 4th April 2011 \\ DOI: 10.1039/c0dt01727b
}

Successful synthesis and investigation of a new material that uses copper-metal-organic frameworks ( $\mathrm{Cu}-\mathrm{MOFs}$ ) as the template for loading $\mathrm{LiBH}_{4}$ are reported. The nanoconfinement of $\mathrm{LiBH}_{4}$ in the pores of $\mathrm{Cu}-\mathrm{MOFs}$ results in an interaction between $\mathrm{LiBH}_{4}$ and $\mathrm{Cu}^{2+}$ ions, enabling the $\mathrm{LiBH}_{4} @ \mathrm{Cu}$ MOFs system to achieve a much lower dehydrogenation temperature than pristine $\mathrm{LiBH}_{4}$.

Since hydrogen has been regarded as a future energy carrier of renewable energy, development of an efficient, robust, safe, and inexpensive hydrogen storage system is needed. ${ }^{1}$ Metal borohydrides $\mathrm{M}\left(\mathrm{BH}_{4}\right)_{n}$ with high hydrogen density have been attracting great interest as potential candidates for advanced hydrogen storage materials. ${ }^{2}$ Among them, lithium borohydride $\left(\mathrm{LiBH}_{4}\right)$, a promising hydrogen storage material, is commercially available and has extremely high theoretical hydrogen capacity (18.3 wt.\%, $121 \mathrm{~kg} \mathrm{~m}^{-3}$ ), but its practical application as a hydrogen storage material is limited due to the high gas-evolution temperature (about $380{ }^{\circ} \mathrm{C}$ ). ${ }^{3}$ Many efforts have been made, with considerable progress, in solving the above-mentioned issues. ${ }^{4}$ For example, the employment of metals, metal halides, oxides, or metal hydrides as catalysts/dopants has been demonstrated to be an appropriate approach to reduce the operating temperature of metal borohydrides. ${ }^{5}$

On the other hand, a recent encouraging approach towards modifying the hydrogen storage properties of $\mathrm{LiBH}_{4}$ has been mainly focused on the identification of nanostructural or porous materials as templates, such as carbon nanotubes, carbon fibers, mesoporous silica, and mesoporous carbon, which provides a strong nanoconfinement effect. ${ }^{6}$ For example, the confinement of $\mathrm{LiBH}_{4}$ in ordered mesoporous $\mathrm{SiO}_{2}$ (SBA-15) ${ }^{6 a}$ and in highly ordered nanoporous hard carbon (NPC) ${ }^{6 b}$ have resulted in significant reduction of the onset desorption temperature. Since metal-organic frameworks (MOFs), which have highly ordered and inherently understandable crystalline lattices, have been used for gas storage, they have become an attractive alternative to the traditional templates for hydrogen storage. ${ }^{7}$ It has been

${ }^{a}$ Department of Materials Science, Fudan University, Shanghai, 200433, China.E-mail: yuxuebin@fudan.edu.cn; Tel: 86-21-55664581

${ }^{b}$ Institute for Superconducting and Electronic Materials, University of Wollongong, NSW 2522, Australia.E-mail: zguo@uow.edu.au

$\dagger$ Electronic supplementary information (ESI) available: Experimental details, results of XRD, DSC, XPS, BET, and density measurements. See DOI: $10.1039 / \mathrm{c} 0 \mathrm{dt} 01727 \mathrm{~b}$ widely demonstrated that MOFs are very effective templates for loading hydrogen storage materials, e.g. ammonia borane (AB) and $\mathrm{NaAlH}_{4}$, to achieve improved kinetics and thermodynamics in hydrogen release. ${ }^{8}$ With these in mind, we selected a kind of $\mathrm{Cu}-$ MOFs (HKUST-1) as the template for loading $\mathrm{LiBH}_{4}$ to clarify the effects of nanoconfinement on the dehydrogenation.

The metal-organic framework template used in this work, HKUST-1 [ $\mathrm{Cu}_{3}(\mathrm{BTC})_{2}\left(\mathrm{H}_{2} \mathrm{O}\right)_{3}, \mathrm{BTC}=$ benzene tricarboxylate], which was prepared according to a procedure in the literature, ${ }^{9}$ has small pore openings with a size of $9 \AA \times 9 \AA$ and can be thermally stable up to $250{ }^{\circ} \mathrm{C}$. The $\mathrm{Cu}_{3}(\mathrm{BTC})_{2}\left(\mathrm{H}_{2} \mathrm{O}\right)_{3}$ sample was heated at $100{ }^{\circ} \mathrm{C}$ for six hours under vacuum to remove the coordinated water molecules to yield dehydrated $\mathrm{Cu}-\mathrm{MOF}$, and the X-ray diffraction (XRD) results are compared in the ESI (Fig. S1†). Taking account of the good solubility of $\mathrm{LiBH}_{4}$ in ether, dehydrated $\mathrm{Cu}-\mathrm{MOF}$ s were mixed with an ether solution of $\mathrm{LiBH}_{4}$ to achieve uniform dispersion and contact, which are indispensable for solid phase reactions. After ultrasonic treatment for ten minutes, the suspension was kept under vacuum for three hours at room temperature to remove the solvent and thus obtain the target compound, $\mathrm{LiBH}_{4} @ \mathrm{Cu}-\mathrm{MOF}$.

The XRD patterns of pristine $\mathrm{LiBH}_{4}$, dehydrated $\mathrm{Cu}-\mathrm{MOF}$, and $\mathrm{LiBH}_{4} @ \mathrm{Cu}-\mathrm{MOFs}$ before and after dehydrogenation are shown in Fig. 1. After loading, the peaks assigned to $\mathrm{Cu}-\mathrm{MOF}$ were still retained with only a slight shift (Fig. 1c), indicating

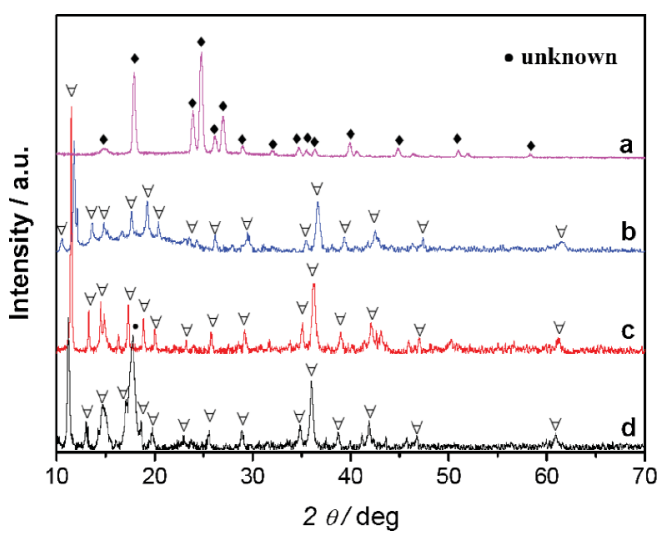

Fig. 1 Powder X-ray diffraction patterns of pristine $\mathrm{LiBH}_{4}$ (a), dehydrated Cu-MOFs (b), LiBH ${ }_{4} @ \mathrm{Cu}-\mathrm{MOF}$ (c), and LiBH $@$ @Cu-MOFs dehydrogenated to $200{ }^{\circ} \mathrm{C}$ (d). (Characteristic peaks assigned to $\mathrm{LiBH}_{4}$ and MOFs are marked by the symbols $\bullet$ and $\forall$, respectively.) 
that the sample has maintained its structural integrity. No peaks corresponding to $\mathrm{LiBH}_{4}$ were found for the $\mathrm{LiBH}_{4} @ \mathrm{Cu}-\mathrm{MOFs}$ sample (Fig. 1c), indicating a successful loading of $\mathrm{LiBH}_{4}$ into the pores of the MOFs. To obtain further evidence that $\mathrm{LiBH}_{4}$ was well absorbed inside the $\mathrm{Cu}-\mathrm{MOFs}$, we compared the volume of pores and the surface area of $\mathrm{Cu}-\mathrm{MOF}$ sefore and after loading by means of Brunauer-Emmett-Teller (BET) measurements, and the results are shown in Fig. S2. $\uparrow$ The $\mathrm{N}_{2}$ adsorption and desorption of $\mathrm{Cu}-\mathrm{MOFs}$ at $77 \mathrm{~K}$ shows the characteristics of a microporous material, while for $\mathrm{LiBH}_{4} @ \mathrm{Cu}-\mathrm{MOFs}$, the measurement shows non-porous characteristics, suggesting the possibility of successful incorporation of $\mathrm{LiBH}_{4}$ into the Cu-MOFs-pores or that the openings in $\mathrm{Cu}-\mathrm{MOF}$ were blocked by the $\mathrm{LiBH}_{4}$ molecules. Further density measurements (ESI $\dagger$ ) revealed that $\mathrm{LiBH}_{4}$ had achieved loading into pores with a filling rate of $84 \mathrm{wt} . \%$, while there was still $16 \mathrm{wt} . \% \mathrm{LiBH}_{4}$ left outside.

As shown in the temperature-programmed desorption (TPD) curves in Fig. S3, $\uparrow$ the dehydrogenation of $\mathrm{LiBH}_{4} @ \mathrm{Cu}-\mathrm{MOF}$ started from around $60^{\circ} \mathrm{C}$, which is dramatically lower than for the pristine $\mathrm{LiBH}_{4}\left(380^{\circ} \mathrm{C}\right)$. After heating up to $200^{\circ} \mathrm{C}$, a total gas release of $0.0048 \mathrm{~mol} \mathrm{~g}^{-1}$ was observed for the $\mathrm{LiBH}_{4} @ \mathrm{Cu}-$ MOFs sample, which indicated partial decomposition of loaded $\mathrm{LiBH}_{4}$ below this temperature $\left(0.007 \mathrm{~mol} \mathrm{~g}^{-1}\right.$ for a complete decomposition of the confined $\mathrm{LiBH}_{4}$ to $\mathrm{H}_{2}$ ).

Mass spectrometry (MS) was used to investigate the temperature profiles of volatile products released from $\mathrm{LiBH}_{4} @ \mathrm{Cu}-\mathrm{MOFs}$ samples. As shown in Fig. 2a, the $\mathrm{LiBH}_{4} @ \mathrm{Cu}-\mathrm{MOFs}$ sample started to release $\mathrm{H}_{2}(m / z=2)$ at around $75{ }^{\circ} \mathrm{C}$, with the peak temperature at $110{ }^{\circ} \mathrm{C}$, while the small peak at $265^{\circ} \mathrm{C}$ should be regarded as the phase transition point of $\mathrm{LiBH}_{4} .^{10}$ The $\mathrm{H}_{2}$-release peak temperature of the MS spectra was a little different from that of the TPD spectra (Fig. S3†), and the main reason would be that mass spectrometry was conducted under $\mathrm{N}_{2}$ atmosphere, while TPD was conducted under an $\mathrm{Ar} / \mathrm{H}_{2}$ atmosphere. Accompanying the evolution of $\mathrm{H}_{2}$, the release of diborane $(m / z=27)$ occurred almost at the same starting and peak temperatures as $\mathrm{H}_{2}$, but was only revealed by a shoulder peak around $205^{\circ} \mathrm{C}$. By combination of the volumetric and gravimetric results, it is determined that the molar ratio of $\mathrm{H}_{2}$ to diborane in the evolved gas is $20: 1$. It is well known that more stable metal borohydrides decompose at higher temperature and release mainly hydrogen, while less stable ones would desorb at lower temperatures and release considerable amounts of diborane byproduct. ${ }^{11 a}$ This effect is mainly due to the nature of diborane,

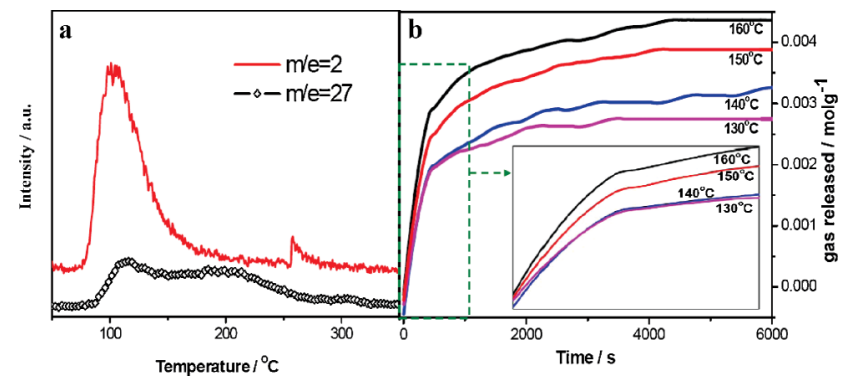

Fig. 2 MS signals of $\mathrm{LiBH}_{4} @ \mathrm{Cu}-\mathrm{MOF}$ (a) and the time dependence of the first-step $\mathrm{H}_{2}$ release plotted from loaded $\mathrm{LiBH}_{4} @ \mathrm{Cu}-\mathrm{MOF}$ at different temperatures (b). The inset in (b) is an enlargement of the dehydrogenation time from 0 to $1000 \mathrm{~s}$. which is reported to decompose at about $250{ }^{\circ} \mathrm{C}$ by thermal decomposition and is not observed as a decomposition product at higher temperature. As reported previously in the literature, ${ }^{11}$ during the decomposition of $\mathrm{LiBH}_{4}$, decreasing the desorption temperature could lead to the emission of diborane, which would accelerate the further decomposition of the remaining $\mathrm{LiBH}_{4}$. Therefore, in our study, the release of diborane may also result from the low decomposition temperature of $\mathrm{LiBH}_{4}$. The differential scanning calorimetry (DSC) result (Fig. S4†) shows a strong endothermal peak for this dehydrogenation, indicating that the dehydrogenation of $\mathrm{LiBH}_{4} @ \mathrm{Cu}-\mathrm{MOF}$ is thermodynamically irreversible. To investigate the distinctly enhanced kinetics of this compound, the time-dependence of the first step dehydrogenation for loaded $\mathrm{LiBH}_{4} @ \mathrm{Cu}-\mathrm{MOFs}$ was measured over a temperature range from 130 to $160^{\circ} \mathrm{C}$, and the results are given in Fig. $2 \mathrm{~b}$. In order to exhibit clearly the different rates of the plots, the time-dependence plots in the range of 0-1000 s were enlarged and are shown in the inset of Fig. 2b. With increasing temperature, the amount of released gas was significantly increased, and the dehydrogenation kinetics was accelerated.

The XRD pattern of the loaded $\mathrm{LiBH}_{4} @ \mathrm{Cu}-\mathrm{MOFs}$ after dehydrogenation shows no change in the structure of the $\mathrm{Cu}$ MOFs (Fig. 1d), which is also confirmed by the Fourier transform infrared (FT-IR) results (Fig. S5†), indicating the stability of the $\mathrm{Cu}-\mathrm{MOF}$ before and after dehydrogenation. However, a strong new peak at $2 \theta=17.8^{\circ}$ can be observed for the dehydrogenated sample, suggesting the formation of a new substance. To explore further details of the decomposition process, solid " ${ }^{11} \mathrm{~B}$ NMR measurements for the samples before and after dehydrogenation to $200{ }^{\circ} \mathrm{C}$ were conducted, as shown in Fig. 3. In the case of the sample before dehydrogenation, the strong peak with the chemical shift of $-41.3 \mathrm{ppm}$ could be assigned to the boron atoms in tetrahedral $\mathrm{BH}_{4}{ }^{-}$groups of $\mathrm{LiBH}_{4}{ }^{12}$ and the much weaker one around $0.19 \mathrm{ppm}$ could be attributed to the slight decomposition of $\mathrm{LiBH}_{4}$ that may occur under the ultrasonic treatment. After dehydrogenation, the peak for the $\mathrm{BH}_{4}{ }^{-}$group still exists due to the residual undecomposed $\mathrm{LiBH}_{4}(16 \mathrm{wt} . \%)$ on the outside surface of the $\mathrm{Cu}-\mathrm{MOF}$ pores, as demonstrated by BET results. Meanwhile, a strong peak at $0.19 \mathrm{ppm}$ appeared after dehydrogenation to $200^{\circ} \mathrm{C}$, which could be assigned to the oxidative product of $\mathrm{LiBH}_{4}$, boric acid. ${ }^{13}$

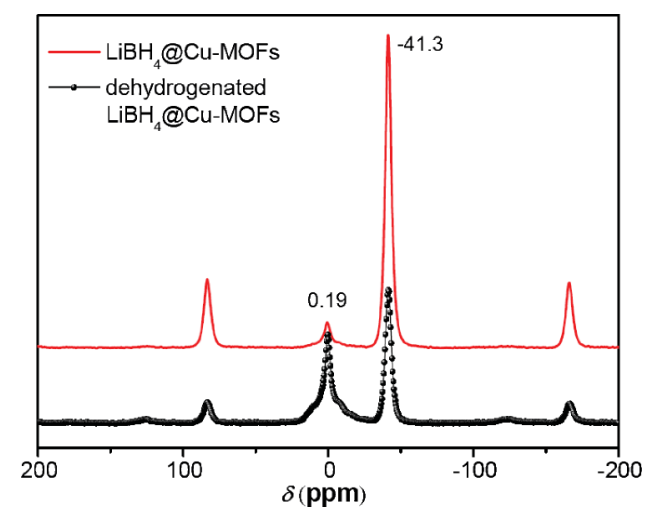

Fig. $3 \quad{ }^{11} \mathrm{~B}$ NMR results for as-prepared $\mathrm{LiBH}_{4} @ \mathrm{Cu}-\mathrm{MOF}$ before and after dehydrogenation at $200{ }^{\circ} \mathrm{C}$. The two pairs of peaks $( \pm 125 \mathrm{ppm}$ and $83.9 /-165.6 \mathrm{ppm}$ ) are regarded as the spinning side bands corresponding to the 0.19 and $-41.3 \mathrm{ppm}$ peaks, respectively. 
In order to clarify the formation of boric acid in the loaded $\mathrm{LiBH}_{4} @ \mathrm{Cu}-\mathrm{MOFs}$ during decomposition, X-ray photoelectron spectroscopy (XPS) of Cu element was conducted, as shown in Fig. S6. $\dagger$ The $\mathrm{Cu} 2 \mathrm{p} 2 / 3$ binding energies shifted from $934 \mathrm{eV}$ for dehydrated Cu-MOFs to $933 \mathrm{eV}$ (loaded sample) and $932.5 \mathrm{eV}$ (dehydrogenated sample), confirming a slight change in the coordination environment of $\mathrm{Cu}$ atoms, that is, the $\mathrm{Cu}$ atoms changed from divalent to mono- or even zerovalent, indicating that a redox reaction had occurred between $\mathrm{LiBH}_{4}$ and the $\mathrm{Cu}^{2+}$ ions in the $\mathrm{Cu}-\mathrm{MOF}$ during decomposition. Given that the product of boric acid in the decomposed $\mathrm{LiBH}_{4} @ \mathrm{Cu}-\mathrm{MOF}$ s is quite similar to that of $\mathrm{LiBH}_{4}$ oxidized by water molecules, a sample with $\mathrm{LiBH}_{4}$ loaded into hydrated $\mathrm{Cu}-\mathrm{MOFs}\left(\mathrm{LiBH}_{4} @ \mathrm{Cu}-\mathrm{MOFs}-\mathrm{H}_{2} \mathrm{O}\right)$ was synthesized and analysed for comparison. Interestingly, it was found that the $\mathrm{LiBH}_{4} @ \mathrm{Cu}-\mathrm{MOF}-\mathrm{H}_{2} \mathrm{O}$ sample showed evident hydrogen release during the loading process, indicating that the coordinated water molecules (one per $\mathrm{Cu}^{2+}$ ion) in the skeleton of the $\mathrm{Cu}-\mathrm{MOF}$ s could react with $\mathrm{LiBH}_{4}$ at room temperature, which opens up a research frontier on the controllable ambient temperature hydrolysis of metal borohydrides by using hydrated MOFs. The ${ }^{11} \mathrm{~B}$ NMR result (Fig. S7 $\dagger$ ) on $\mathrm{LiBH}_{4} @ \mathrm{Cu}-\mathrm{MOFs}-$ $\mathrm{H}_{2} \mathrm{O}$ indicated the formation of boric acid, with peaks appearing at around $0.19 \mathrm{ppm}$, again confirming the redox reaction in the $\mathrm{LiBH}_{4} @ \mathrm{Cu}-\mathrm{MOFs}$ system, while the presence of the peak at -41 ppm, corresponding to $\mathrm{LiBH}_{4}$, suggests that the residual $\mathrm{LiBH}_{4}$ on the outside surface of the $\mathrm{Cu}-\mathrm{MOF}$ did not react with the $\mathrm{H}_{2} \mathrm{O}$ in the hydrated MOFs as well. The above results indicate that $\mathrm{LiBH}_{4}$ could dehydrogenate at low temperature through a redox reaction with $\mathrm{Cu}-\mathrm{O}$ units or $\mathrm{H}_{2} \mathrm{O}$ in the $\mathrm{Cu}-\mathrm{MOF}$. However, this reaction only occurs for the $\mathrm{LiBH}_{4}$ confined in the pores of MOFs.

For a better understanding of the reaction between $\mathrm{LiBH}_{4}$ and $\mathrm{Cu}^{2+}$ ions after nanoconfinement, the schematic diagram in Fig. 4 was drawn to give an impression of the architecture: one $\mathrm{LiBH}_{4}$ molecule is trapped per $\mathrm{Cu}^{2+}$ ion inside the "pore" of the $\mathrm{Cu}$ MOFs, and the interaction between $\mathrm{LiBH}_{4}$ and the $\mathrm{Cu}^{2+}$ ions is expressed by the dotted lines. Given the small pore size with diameter of $0.9 \mathrm{~nm}$, the interaction may become easier between the $\mathrm{LiBH}_{4}$ and $\mathrm{Cu}^{2+}$ ions after loading. In addition, after removal of the coordinated water molecules, the active coordination sites

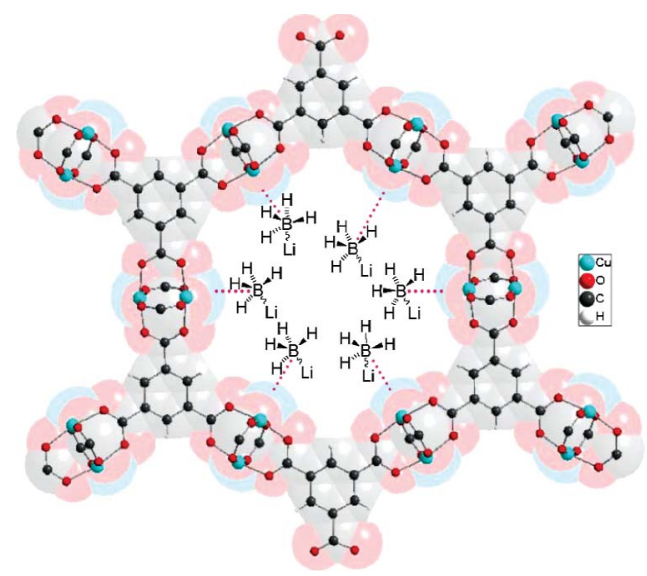

Fig. 4 Schematic diagram of $\mathrm{LiBH}_{4}$ molecules loaded into the pores of Cu-MOFs. (The interaction between the $\mathrm{LiBH}_{4}$ and the $\mathrm{Cu}^{2+}$ ions is indicated by the dotted lines.) of copper atoms that exist in the dehydrated Cu-MOFs could further promote the interaction. The above hypothesis can be confirmed by a direct mixing of $\mathrm{LiBH}_{4}$ and $\mathrm{Cu}-\mathrm{MOF}$, in which only a trace of gas evolution was observed on heating the sample to $200{ }^{\circ} \mathrm{C}$ (Fig. S4 $\dagger$ ). Therefore, nanoconfinement of $\mathrm{LiBH}_{4}$ in the pores of MOFs is a crucial factor for igniting the redox reaction between $\mathrm{LiBH}_{4}$ and $\mathrm{Cu}-\mathrm{O}$ units, which could achieve superior dehydrogenation properties in this system compared to other $\mathrm{LiBH}_{4}$ systems with oxide dopants. ${ }^{5 a, 5 c}$

In conclusion, we have selected a special kind of Cu-MOFs as the template for loading $\mathrm{LiBH}_{4}$ to produce a possible hydrogen storage material. The confinement by nanostructural materials and the consequent redox reaction between $\mathrm{LiBH}_{4}$ and $\mathrm{Cu}-\mathrm{O}$ units enabled dehydrogenation to occur in $\mathrm{LiBH}_{4} @ \mathrm{Cu}-\mathrm{MOFs}$ at a much lower dehydrogenation temperature. Such nanoconfinement could be widely used in cooperation with other positive effects, such as: redox, catalysis, or hydrolysis reactions, to achieve the potential for hydrogen storage materials with vastly improved dehydrogenation.

\section{Acknowledgements}

This work was partially supported by the National Natural Science Foundation of China (Grant No. 51071047), the Program for New Century Excellent Talents in Universities (NCET-08-0135), the Australian Research Council (DP0878661), and the PhD Programs Foundation of the Ministry of Education of China (20090071110053). We thank Dr Tania Silver for her critical reading of this paper.

\section{Notes and references}

1 (a) W. Grochala and P. P. Edwards, Chem. Rev., 2004, 104, 1283; (b) M. S. Dresselhaus and I. L. Thomas, Nature, 2001, 414, 332; (c) L. Schlapbach and A. Züttel, Nature, 2001, 414, 353; (d) Y. F. Liu, K. Zhong, K. Luo, M. X. Gao, H. G. Pan and Q. D. Wang, J. Am. Chem. Soc., 2009, 131, 1862.

2 (a) S. I. Orimo, Y. Nakamori, J. R. Eliseo, A. Züttel and C. M. Jensen, Chem. Rev., 2007, 107, 4111; (b) P. Edwards, W. Grochala, D. Book, I. R. Harris, International Patent WO2004096700, 2004; (c) H. W. Li, K. Kikuchi, Y. Nakamori, K. Miwa, S. Towatab and S. Orimo, Scripta Mater., 2007, 57, 679.

3 (a) E. M. Fedneva, V. L. Alpatova and V. I. Mikheeva, Russ. J. Inorg. Chem. (Transl. of Zh. Neorg. Khim.), 1964, 9, 826; (b) A. Züttel, P. Wenger, S. Rentsch, P. Sudan, Ph. Mauron and Ch. Emmenegger, J. Power Sources, 2003, 118, 1.

4 (a) J. J. Vajo and G. L. Olson, Scripta Mater., 2007, 56, 829; (b) M. Aoki, K. Miwa, T. Noritake, G. Kitahara, Y. Nakamori, S. Orimo and S. Towata, Appl. Phys. A: Mater. Sci. Process., 2005, 80, 1409; (c) G. P. Meisner, M. L. Scullin, M. P. Balogh, F. E. Pinkerton and M. L. Meyer, J. Phys. Chem. B, 2006, 110, 4186; (d) G. Barkhordarian, T. Klassen and R. Bormann, J. Phys. Chem. B, 2006, 110, 11020.

5 (a) X. B. Yu, D. M. Grant and G. S. Walker, Chem. Commun., 2006, 3906; (b) Y. H. Guo, X. B. Yu, L. Gao, G. L. Xia, Z. P. Guo and H. K. Liu, Energy Environ. Sci., 2010, 3, 465; (c) X. B. Yu, D. A. Grant and G. S. Walker, J. Phys. Chem. C, 2008, 112, 11059; (d) J. J. Vajo and S. L. Skeith, J. Phys. Chem. B, 2005, 109, 3719.

6 (a) P. Ngene, P. Adelhelm, M. B. Andrew, K. P. de Jong and P. E. de Jongh, J. Phys. Chem. C, 2010, 114, 6163; (b) X. F. Liu, D. Peaslee, C. Z. Jost and E. H. Majzoub, J. Phys. Chem. C, 2010, 114, 14036; (c) A. F. Gross, J. J. Vajo, S. L. Van Atta and G. L. Olson, J. Phys. Chem. C, 2008, 112, 5651.

7 (a) N. L. Rosi, J. Eckert, M. Eddaoudi, D. T. Vodak, J. Kim, M. O'Keeffe and O. M. Yaghi, Science, 2003, 300, 1127; (b) J. L. C. Rowsell and O. M. Yaghi, Angew. Chem., Int. Ed., 2005, 44, 4670; (c) B. Chen, N. W. Ockwig, A. R. Millward, D. S. Contreras and O. M. Yaghi, Angew. Chem., Int. Ed., 2005, 44, 4745. 
8 (a) Z. Y. Li, G. S. Zhu, G. Q. Lu, S. L. Qiu and X. D. Yao, J. Am. Chem. Soc., 2010, 132, 1490; (b) R. K. Bhakta, J. L. Herberg, B. Jacobs, A. Highley, R. Behrens, Jr., N. W. Ockwig, J. A. Greathouse and M. D. Allendorf, J. Am. Chem. Soc., 2009, 131, 13198.

9 (a) S. S. Y. Chui, M. F. L. Samuel, J. P. H. Charmant, A. G. Orpen and I. D. Williams, Science, 1999, 283, 1148; (b) K. Schlichte, T. Kratzke and S. Kaskel, Microporous Mesoporous Mater, 2004, 73, 81.

10 H. I. Schlesinger and H. C. Brown, J. Am. Chem. Soc., 1940, 62, 3429.
11 (a) O. Friedrichs, A. Remhof, S. J. Hwang and A. Züttel, Chem. Mater., 2010, 22, 3265; (b) O. Friedrichs, A. Borgschulte, S. Kato, F. Buchter, R. Gremaud, A. Remhof and A. Züttel, Chem.-Eur. J., 2009, 15, 5531.

12 (a) S. J. Hwang, R. C. Bowman, Jr., J. W. Reiter, J. Rijssenbeek, G. L. Soloveichik, J. C. Zhao, H. Kabbour and C. C. Ahn, J. Phys. Chem. $C, 2008,112$, 3164; (b) M. Au, A. R. Jurgensen, W. A. Spencer, D. L. Anton, F. E. Pinkerton, S.-J. Hwang, C. Kim and R. C. Bowman, Jr., J. Phys. Chem. C, 2008, 112, 18661.

13 R. L. Corey, D. T. Shane, R. C. Bowman, Jr. and M. S. Conradi, J. Phys. Chem. C, 2008, 112, 19784. 